\title{
COMPENSATION FOR DAMAGES DUE TO A FAILURE TO PERFORM A CONTRACTUAL OBLIGATION IN A PURCHASE AND SALES CONTRACT IN FOREIGN TRADE OPERATIONS
}

\begin{abstract}
One of the oldest human activities is the trade of goods, services, money and other property values both within a country and abroad. Foreign trade business has an exceptional importance for socio-economic relations between countries. Each state independently regulates the trade of goods and services. However, no state economy is self-sufficient, so its need to join the international markets is quite justified. Through a mutual trade cooperation, states transfer the effects of the concluded agreements beyond their borders, and the need for the unification of certain norms is absolutely necessary, as well as the regulation of the issue of a breach of contractual obligation and compensation for damages as a consequence resulting from such a thing. Some countries have a fear of ratifying the international rules, because they think that the accepted solutions would be contrary to their national legislation. There is mentioned only one of the reasons for the states resistance, as well as the difficulties in achieving the unique acceptable solution. This paper analyzes the concept, the importance of foreign trade business for countries, then the rights and obligations of the contracting parties and the compensation for damage due to a breach of a contractual obligation by non-performance in the sales contract.
\end{abstract}

\footnotetext{
* LLM, A teaching Assistant and PhD student, The Faculty of Law for Commerce and Judiciary in Novi Sad, The University of Business Academy in Novi Sad, e-mail: tanja.prastalo@pravni-fakultet.info ** LLD, A full Professor, The Faculty of Law for Commerce and Judiciary in Novi Sad, The University of Business Academy in Novi Sad, e-mail: d.djurdjev@pravni-fakultet.info
} 
Keywords: foreign trade operations, rights and obligations from the sales contract, non-performance of the contractual obligation, Vienna Convention, compensation for damages.

\section{Introduction}

The most developed trading cities of Italy ${ }^{1}$ unified the first trade rules in the 12th and 13th centuries, thanks to the center of world trade - the Mediterranean. The emergence of commercial law as a special branch of law occurred in the Middle Ages, within the feudal social order where each feudal estate represented a state in miniature, with special legal rules prescribed by the feudal lord. ${ }^{2}$ With the further development of trade, there is a need for more precise regulation of certain issues. Namely, every year, every state tries to listen to the requests and needs of its citizens, and takes certain measures in order to develop it socially and economically. Many countries have not reached the set goal when it comes to its economic development, and it is very possible that they will never. Yet, even those countries do not give up on their goals and take all steps to achieve them.

The soil and water of the state, including prominent citizens in terms of contribution to their country ${ }^{3}$, provide wealth that the state skillfully exploits in its own interest. However, states need mutual cooperation, because they are not in themselves strong enough to satisfy all possible needs of its citizens. Hence the need for import, export of goods and services and other values.

Namely, the desire to import foreign goods and place one's own goods, i.e. to expand the placement of domestic goods on international markets, is more pronounced in developing countries than in developed countries. In developing countries, foreign trade is an opportunity to provide wealth that the state skillfully exploits in its own interest. However, states need mutual cooperation, because they are not in themselves strong enough to satisfy all possible needs of its citizens.

Hence the need for import, export of goods and services and other values. Namely, the desire to import foreign goods and place one's own goods, i.e. to expand the placement of domestic goods on international markets, is more pronounced in developing countries than in developed countries. In developing countries, foreign trade is an opportunity to provide wealth that

\footnotetext{
${ }^{1}$ Venice, Pisa, etc.

${ }^{2}$ Antonijević, Z. (1967). Pravo spoljne trgovine [Foreign trade law]. Beograd, Prosveta. p. 3.

${ }^{3}$ Especially the young.
} 
the state skillfully exploits in its own interest. However, states need mutual cooperation, because they are not in themselves strong enough to satisfy all possible needs of its citizens. Hence the need for import, export of goods and services and other values. Namely, the desire to import foreign goods and place one's own goods, i.e. to expand the placement of domestic goods on international markets, is more pronounced in developing countries than in developed countries. In developing countries, foreign trade is an opportunity, that is, the expansion of the placement of domestic goods on international markets is more pronounced in developing countries than in developed countries. In developing countries, foreign trade is an opportunity, that is, the expansion of the placement of domestic goods on international markets is more pronounced in developing countries than in developed countries. In developing countries, foreign trade is an opportunity to they place their products, change them and in that way supply their citizens, as well as accelerate the economic development of the state. In order to achieve general goals, the state is forced to accept certain solutions that its domestic legislation does not support. However, the voluntary element when concluding a contract must not be neglected, ie that the contracting parties have the freedom to choose whether they want to conclude a contract at all, with whom they want to conclude a contract, what content, under what conditions and circumstances, and in foreign trade choice of applicable law, as well as to agree on determining the jurisdiction of the court if there are reasons for resolving disputes, etc. It is this voluntary element, ie internal motivation - the interest of the contracting parties, as well as the fear in case of non-fulfillment of the contractual obligation, it is conditioned by the precision of contracting crucial points, ie essential elements of the contract, especially the issue of breach of contractual obligation as non-performance or delay in fulfilling it, means of security and jurisdiction of the court.

The continuous development of the economy and the placement of various achievements on the markets, both at the national and international level, the need for unification of rules that would be applied to certain situations was increasingly pronounced. Also, once adopted and accepted rules could not remain unchanged, since modern sciences and techniques are changing, due to technical - technological development, or evolving, and thus the "practice" of foreign trade means of security and jurisdiction of the court. The continuous development of the economy and the placement of various achievements on the markets, both at the national and international level, the need for unification of rules that would be applied to certain situations was increasingly pronounced. Also, once adopted and accepted rules could not remain 
unchanged, since modern sciences and techniques are changing, due to technical - technological development, or evolving, and thus the "practice" of foreign trade means of security and jurisdiction of the court. The continuous development of the economy and the placement of various achievements on the markets, both at the national and international level, the need for unification of rules that would be applied to certain situations was increasingly pronounced. Also, once adopted and accepted rules could not remain unchanged, since modern sciences and techniques are changing, due to technical - technological development, or evolving, and thus the "practice" of foreign trade.

\section{The concept of foreign trade}

The concept of foreign trade, in the broadest sense of the word, includes regular exchange of goods and services with foreign countries in the form of permanent and professional activities, which is the part of turnover in which the exchange is done by the subject of sale of one country (export) or enters the territory of the buyer's country (import). ${ }^{4}$

Thus, foreign trade is the trade of goods and services between two or more countries under certain conditions. Foreign trade legal regime of states and free customs territories. depends on national regulations, as an expression of foreign trade policy, as well as on internationally adopted norms in the field of trade in goods, services and capital. ${ }^{5}$

States reserve the right to grant certain benefits to certain states, which further encourages foreign trade. The basis for determining individual privileges among countries is based mainly on the principle of reciprocity. ${ }^{6}$

Foreign trade is the turnover between domestic and foreign persons which is performed on the basis of contracts concluded in accordance with domestic regulations and international agreements. In order to call business foreign, it is necessary to add an element of foreignness. ${ }^{7}$ In most countries, in order for a contract of purchase and sale to be considered a foreign trade business, it is necessary to meet certain conditions, eg: ${ }^{8}$ the element of foreignness, that

\footnotetext{
${ }^{4}$ Tešić, M. (1977). Spoljnotrgovinsko poslovanje [Foreign trade business]. Beograd, Savremena administracija. p. 11.

${ }^{5}$ Ćirić, A. (2013). Pravo spoljne trgovine [Foreign trade law]. Niš, Centar za publikacije Pravnog fakulteta u Nišu, p. 5.

${ }^{6}$ Principle of reciprocity - reciprocity. One state will allow privilege to the citizens of another state, if the citizens of the state that allowed the privilege have equal treatment in that state.

${ }^{7}$ Zakon o spoljnotrgovinskom poslovanju [Law on Foreign Trade Operations], Službeni glasnik $R S$, br. 36/09, 36/11 - dr. zakon, 88/11 i 89/15 - dr. zakon, Article 2, paragraph 1.

${ }^{8}$ Antonijević, Z., op.cit., p. 96.
} 
both contracting parties (in some countries one contracting party) have the status of a trader under their national legislation, that for both parties the contract is a commercial business, that the subject of the contract is the movement of goods. The element of foreignness may appear in the subject ${ }^{9}$, object $^{10}$ or in the rights and obligations ${ }^{11}$ of the contracting parties.

\section{Vienna Convention}

The most common foreign trade contract is a sales contract. In addition to domestic regulations, international regulations also apply to sales contracts. The United Nations Convention on Contracts for the International Sale of Goods is a multilateral treaty that introduces a single law on sales that has so far been ratified by 83 states. The agreement was signed in Vienna, hence the name Vienna Convention. It regulates the most important provisions of the sales contract, but in addition to the above, there are still legal obstacles that are filled by the application of domestic regulations.

Having in mind what has been stated so far, it is concluded that the states, regardless of the resistance they offered, which were justified for certain prominent reasons, were "forced" to accept certain uniform solutions for the sake of the general interest.

Namely, it would be impossible to imagine the trade of goods and services, ie sales between two or more countries with unequal solutions in terms of basic legal issues of regulating one contract. The United Nations Convention on Contracts for the International Sale of Goods was adopted on April 11, 1980. ${ }^{12}$ It represents a revision of the Hague Act on the International Sale of Bodies of Movable Property from 1964. The conventions on the uniform laws of the Hague entered into force, but Yugoslavia did not ratify them, because the process of their revision began immediately after the establishment of UNICITRAL. ${ }^{13}$ The shortcomings that the states saw in the Hague laws were removed by the Convention. ${ }^{14}$

\footnotetext{
${ }^{9}$ Citizenship, domicile of persons, residence, seat of legal entity.

${ }^{10}$ Having in mind the place where the thing was found, the affiliation of the same.

${ }^{11}$ If, for example, a legal business was created abroad.

${ }^{12}$ Vilus, J. (1985). Konvencija Ujedinjenih nacija o ugovorima i međunarodnoj prodaju robe Bečka konvencija [United Nations Convention on Contracts and the International Sale of Goods - Vienna Convention]. Beograd, Jugoslavija publik, p. 5.

${ }^{13}$ Ibid.

${ }^{14}$ Goldštajn, A. (1980). Konvencija Ujedinjenih naroda o ugovorima o međunarodnoj prodaji robe u strukturi prava međunarodne trgovine [United Nations Convention on Contracts for the International Sale of Goods in the Structure of International Trade Law]. Zagreb, Informator, p. 8.
} 
The Vienna Convention takes precedence over domestic law, it applies as a lex specialis. The significance of the Convention is enormous, since its adoption provided security to businessmen, as well as international traffic in general. The goal of its adoption is the development of international trade on the basis of equality and mutual benefit as a significant element of improving, in a way, friendly relations between countries.

Pursuant to Article 1 of the Convention, it applies to contracts for the sale of goods concluded between parties having their registered offices in the territories of different States when those Contracting States or rules of private international law refer to the application of the law of a Contracting State.

The Parties may exclude the application of the Convention. ${ }^{15}$ The Contracting Parties are bound by the customs with which they have agreed, as well as the practice established between them, and unless otherwise agreed, the Parties shall be deemed to have tacitly subjected their contract or its conclusion to a custom which was or must have been known to them. known in international trade and regularly respected by the contracting parties in contracts of the same type in the respective profession. ${ }^{16}$

Thus, in addition to the adopted and accepted solutions, the Convention gives freedom to the parties to the contractual relationship to regulate certain issues differently, i.e. the usual rules if they have explicitly agreed, or have tacitly subjected the contract to the same. In this way, it can be noticed that the rules adopted within the framework of the convention are of a dispositive character and that they are based on a fundamental principle, which is the autonomy of the will of the contracting parties, that is, freedom of contract, which was discussed in the introduction.

\section{Rights and obligations of the contracting parties from the contract of sale take over the thing.}

According to the Law on Obligations ${ }^{17}$, the contract of sale obliges the seller to transfer to the buyer the right of ownership of the sold thing and to hand it over to him for that purpose, and the buyer is obliged to pay the price in cash and take over the thing.

\footnotetext{
${ }^{15}$ Article 6 Zakona o ratifikaciji konvencije Ujedinjenih nacija o ugovorima o međunarodnoj prodaji robe [Law on Ratification of the United Nations Convention on Contracts for the International Sale of Goods], Službeni list SFRJ Međunarodni ugovori, br. 101/84.

${ }^{16}$ Ibid., Article 9.

${ }^{17}$ Ibid, Article 9.
} 
The seller is obliged to deliver the goods, hand over the documents related to the goods and transfer the ownership of the goods in the manner stipulated by the contract and the Convention. ${ }^{18}$ The debtor's obligation is to pay the agreed price within the agreed time. If the debtor fulfills his obligation, the obligation relationship is terminated, the obligation ceases.

If the debtor fails to fulfill his obligation or is late in fulfilling it, the other contracting party has the right to demand damages. The amount of compensation is determined by the court in the court procedure initiated by the creditor. ${ }^{19}$ The amount of damages can be reduced proportionally if the creditor is partly to blame for the damage. ${ }^{20}$ The party alleging breach of contract shall take all reasonable steps in the circumstances of the case to reduce the loss, including lost profits, caused by such breach. ${ }^{21}$ If he fails to do so, the other party may claim a reduction in compensation in the amount of the avoidable loss. ${ }^{22}$

Pursuant to the Law on Obligations, ${ }^{23}$ damage is the reduction of someone's property (ordinary damage) and the prevention of its increase (lost benefit), as well as causing physical or mental pain or fear (non-material damage) to another. Material damage affects the property of the injured party, directly (actual damage), when it is reflected in the reduction of his property, or indirectly (lost profit), when it comes to preventing its increase, which would have occurred according to the regular course of events. ${ }^{24}$

Under the Vienna Convention, ${ }^{25}$ compensation for breach of contract committed by one party is equal to the loss suffered and the loss of profits incurred by the other party as a result of the breach. This compensation may not exceed the loss foreseen or had to be foreseen by the party infringing the contract at

\footnotetext{
${ }^{18}$ Article 454, paragraph 1, Zakona o obligacionim odnosima [Law on Obligations], Službeni list SFRJ, br. 29/78, 39/85, 45/89 - odluka USJ i 57/89, Službeni list SRJ, br. 31/93 i Službeni list SCG, br. $1 / 03$ - Ustavna povelja.

${ }^{19}$ Article 30 Zakona o ratifikaciji konvencije Ujedinjenih nacija o ugovorima o međunarodnoj prodaji robe [Law on Ratification of the United Nations Convention on Contracts for the International Sale of Goods], op. cit.

${ }^{20}$ Radovanov, A. (2009). Obligaciono pravo - opšti deo [Obligation law - general part]. Novi Sad, Pravni fakultet za privredu i pravosuđe, Univerzitet Privredna akademija u Novom Sadu, p. 66.

${ }^{21}$ Article 77 Zakona o ratifikaciji konvencije Ujedinjenih nacija o ugovorima o međunarodnoj prodaji robe [Law on Ratification of the United Nations Convention on Contracts for the International Sale of Goods], op. cit.

${ }^{22}$ Ibid.

${ }^{23}$ Article 155 Zakona o obligacionim odnosima [Law on Obligations], op. cit.

${ }^{24}$ Antić, O. (2009). Obligaciono pravo [Obligation law]. Beograd, Službeni glasnik, p. 448.

${ }^{25}$ Article 74 Zakona o ratifikaciji konvencije Ujedinjenih nacija o ugovorima o međunarodnoj prodaji robe [Law on Ratification of the United Nations Convention on Contracts for the International Sale of Goods], op. cit.
} 
the time of the conclusion of the contract as a possible consequence of the breach of contract, given the facts then known or must have been known to it.

If one party does not pay the price or some other amount with which it is in arrears, the other party is entitled to interest on such amount, without losing the right to claim damages due to it on the above grounds. ${ }^{26}$

Namely, according to the opinion of the Commercial Court of Appeals, ${ }^{27}$ by terminating the contract on the international sale of goods, the seller, who is obliged to return the price, must also pay interest on it, starting from the day when the price was paid to him. From the explanation: "According to the facts established in the first-instance procedure, the litigants were in a business relationship on the basis of a contract of sale with an element of foreignness, given that the plaintiff is a company that has the nationality of the Republic of $\mathrm{BiH}$. On that basis, the defendant, as a seller, undertook to deliver to the plaintiff, as a buyer, an automatic machine for making fax, adding and thermal roll model " $1+1$ " within 30 days, which period began on June 27, 2008. year, at a price of 7,000.00 euros. On that basis, the plaintiff paid the defendant the total amount on two occasions of 7,000.00 euros, so that as of August 19, 2008. years, he paid the price for the machine in question in full. The defendant was late with the delivery of the machine in question, which is why the plaintiff sent him a letter dated October 8, 2008. called for the delivery of the machine as soon as possible or to return the price to him, since the defendant was three months late in delivering the machine.

The defendant did not act on that summons of the plaintiff and did not deliver the machine that was the subject of the sales contract until the day the lawsuit was filed, nor did he submit evidence to the court that he returned the money he received in the name of the price for the said machine to the plaintiff. The plaintiff is seeking the return of the amount he paid in the name of the price for the machine that was supposed to be the subject of the contract of sale with default interest prescribed by the Law on the amount of default interest rate starting from October 8,2008. years, as the day when he called the prosecutor or to deliver the machine to him or to return the money. The first-instance court correctly applied the substantive law to the established factual situation when it concluded that in the specific case, and having in mind that the litigants did not agree on the application of the applicable law in case of dispute, the relevant United Nations Convention on Contracts for the International Sale of Goods Vienna Convention ( hereinafter: the Convention), and pursuant to Art. 53 and

\footnotetext{
${ }^{26}$ Ibid, Article 78.

${ }^{27}$ Judgment of the Commercial Court of Appeal, Pž. 10784/2010 of 6 July 2011 years.
} 
54 of the Convention, the plaintiff rightly demands a refund of the price, as a consequence of the termination of the contract.

However, the conclusion of the first instance court that the plaintiff was on the day of filing the lawsuit, more precisely on February 24, 2010, is wrong. undoubtedly expressed his will to terminate the contract, which produced legal effect from the day when the defendant was notified, ie on March 25, 2010. when the defendant received the lawsuit, and that therefore, Pursuant to Article 78 of the Convention, the right to default interest belongs as of March 25, 2010. years until payment.

This is because the provision of Article 81, paragraph 1 of the Convention stipulates that upon termination of the contract, both parties are released from their contractual obligations, except for the possible obligation to compensate the damage. Termination does not affect the provision of the dispute settlement agreement, any provision of the contract governing the rights and obligations of the parties after the termination of the contract, while Article 81 $\S 2$ of the Convention provides that the party who executed the contract may request in whole or in part from the other party. return of what it has delivered or paid under the contract. If both parties are obliged to make a return, mutual returns are made at the same time. The provision of Article $84 \S 1$ of the Convention provides that if the seller is obliged to reimburse the price, he must also pay interest on it starting from the day the price is paid to him. In the present case, the defendant, as the seller, is obliged to reimburse the price he received in full, and pursuant to Article $84 \S 1$ of the Convention, he is required to pay interest from the date on which the price was paid.

However, as the plaintiff demanded interest on the paid price starting from October 8, 2008. year, the Commercial Court of Appeals, moving within the limits of the request placed in the procedure pursuant to Article 3, paragraph 1 of the Law on Civil Procedure, changed the first instance verdict in the challenged part and awarded the plaintiff default interest at the rate prescribed by the Law on Default Interest from 8.10.2008. years, until March 24, 2010. The Commercial Court of Appeal correctly ruled although Article $84 \S$ $1^{28}$ of the Vienna Convention was expressly provided for, without a basis for interpreting it in a different way. Furthermore, the position of the court regarding the time from which the interest is calculated is correct, since the court cannot award the parties in the procedure more rights than the party requested, ie the court judges within the framework of the filed claim. As the plaintiff

\footnotetext{
${ }^{28}$ If the seller is obliged to return the price, he must also pay interest on it starting from the day when the price was paid to him.
} 
demanded interest from October 8, 2008. year, the court could not in the operative part of the judgment oblige the defendant to pay interest from the date of payment as expressly provided by the said Article of the Convention.

\section{Substantial breach of contract}

From the definition of material breach adopted in the Vienna Convention, two basic criteria can be observed, namely the criterion of damage - which essentially deprives the other party of what it reasonably expected from the contract and the criterion of predictability of damage by a reasonable person of the same circumstances. ${ }^{29}$ Therefore, when assessing the question of whether the breach of contract is significant, we start from a subjective criterion, ie. the significance of the interest that the contracting party justifiably expected from the contract and the existence of damage that deprives it, if such damage is determined, the violation will be considered significant only if the party making the violation did not foresee such a consequence, nor would a reasonable person of the same characteristics in the same circumstances. ${ }^{30}$

When assessing the significance of a breach of contract, one should start not only from a subjective criterion, but from a subjective-objective criterion, for the reason that the subjective criterion limits the objective one. ${ }^{31}$

Due to a significant breach of contract, the other party has no interest in keeping the contract in force. As in the mentioned specific case, by non-performance of the contractual obligation as one of the cases in which there is a breach of contract, by the defendant, the plaintiff, ie the buyer requested a refund of the paid money. The buyer waited for 3 months and warned the plaintiffseller several times to deliver the purchase of the machine, which he did not do. If there was a basis, the plaintiff-buyer could have sought the lost benefit, if he really suffered it. ${ }^{32}$ A party who claims to have a right, bears the burden of proving a fact that is important for the emergence or exercise of rights. ${ }^{33}$ The lost

\footnotetext{
${ }^{29}$ Perović, J. (2004). Bitna povreda ugovora - međunarodna prodaja robe [Significant breach of contract - International sale of good]. Beograd, JP Službeni list SCG, p. 131.

${ }^{30}$ Ibid.

${ }^{31}$ In the event of a dispute, the contracting party will always claim more than expected in the lawsuit. As according to the CAP, the burden of proof is on the party claiming something, the court will appreciate the evidence submitted by the party making the allegations. Therefore, not only on the basis of subjective criteria, but also on the basis of the evidence (objectively) that he presented as evidence in order to substantiate the allegations made.

${ }^{32}$ Perhaps the same machines were necessary for further delivery, or use.

${ }^{33}$ Article 231, paragraph 2 Zakona o parničnom postupku [Law on Civil Procedure], Službeni glasnik RS, br. 72/11, 49/13 - odluka US, 74/13 - odluka US, 55/14 i 87/18.
} 
benefit is the profit that the creditor could have made if the contract had been duly fulfilled, but he did not realize it (he missed it) because the debtor violated the contract. ${ }^{34}$ The Vienna Convention, in Article 74, prescribes lost profits as a type of damage resulting from an injury caused to the other party, which is the basis for claiming damages.

When one party fails to fulfill its obligation, which it is obliged to fulfill according to the contract, then the other contracting party has the right to terminate the contract. ${ }^{35}$ The contract can be terminated due to non-fulfillment of the contractual obligation, however, due to non-fulfillment of an insignificant part of the obligation, it cannot. In bilateral agreements, when one party fails to fulfill its obligation, the other party may, unless otherwise specified, demand fulfillment of obligations, terminate the agreement by a simple statement, if the termination of the contract does not occur according to the law itself, and in any case he is entitled to compensation. ${ }^{36}$ The creditor may maintain the contract in force, if after the expiration of the term, without delay, he notifies the debtor to request the fulfillment of the contract. ${ }^{37}$ Furthermore, in the case of contracts where the deadline for the fulfillment of the obligation is not an important element, the debtor reserves the right to fulfill his obligation even after the expiration of the deadline, and the creditor to demand its fulfillment. But, if the creditor wants to terminate the contract, he must leave the debtor a reasonable subsequent deadline for fulfillment. ${ }^{38}$ Certainly, the party that terminates the contract due to non-fulfillment, is obliged to inform the other party. Pursuant to the Law on Obligations, the creditor may terminate the contract without leaving the debtor a subsequent deadline for fulfillment if it follows from the debtor's conduct that he will not fulfill his obligation even within the subsequent deadline. ${ }^{39}$ Thus, the debtor's conduct regarding the fulfillment of his contractual obligation can be the basis of the creditor's authority to terminate the contract not only without setting a new, subsequent deadline, but also before the debtor's obligations fall due. ${ }^{40}$

\footnotetext{
${ }^{34}$ Jankovec, I. (1987). Naknada za štetu zbog povrede ugovora [Compensation for damage due to breach of contract]. Beograd, Zavod za organizaciju poslovanja i obrazovanje kadrova p. 45.

${ }^{35}$ Bikić, A. (2007). Obligaciono pravo - opći deo [Obligation law - general part], Sarajevo, Pravni fakultet Univerziteta u Sarajevu, p. 188.

${ }^{36}$ Article 124 of the Law on Obligations.

${ }^{37}$ Ibid., Article 125, para. 2.

${ }^{38}$ Ibid., Article 126, para. 2.

${ }^{39}$ Ibid., Article 127.

${ }^{40}$ Đorđević, Ž., Stanković, S. (1987). Obligaciono pravo - opšti deo [Obligation law - general part]. Beograd, IRO Naučna knjiga, p. 316.
} 
It is concluded that neither the legislator nor the Convention advocates the termination of the contract "primarily" of non-fulfillment of the contractual obligation, but allows the contracting parties to keep it in force. The position is justified, since the contracting parties voluntarily entered into an obligatory relationship, with a certain motive, which is especially pronounced in foreign trade operations, and any legally formulated legal provision would be repressive. This is also prescribed by the Vienna Convention. ${ }^{41}$

It is presumed the fault of the party that fails to fulfill its obligation on time, or is late in fulfilling it. This is, however, a rebuttable assumption. A contracting party who has not performed an obligation may prove that the cause of non-performance of the contractual obligation arose due to a case or force majeure and if he proves a justified circumstance, the contract will be terminated due to the impossibility of fulfillment.

With regard to the manner of resolving foreign trade disputes, the contracting parties, in foreign trade, shall agree on the arbitral settlement of disputes. Prior to the arbitration of a dispute, the parties almost always state in the contract itself a clause on peaceful settlement of disputes, in a friendly manner, but almost always give priority to arbitration, in relation to dispute resolution before the courts of the country. In this way, the parties to the contractual relationship protect their rights, but also their interests, in a fair and equal manner. It is almost impossible for one party to know all the rights of the states of the other contracting parties with which it concludes international agreements, and that ignorance of the rights could be to its detriment, and we must not ignore the fact that proceedings before regular courts can take a long time. in foreign trade, agree on arbitral settlement of disputes. Prior to the arbitration of a dispute, the parties almost always state in the contract itself a clause on peaceful settlement of disputes, in a friendly manner, but almost always give priority to arbitration, in relation to dispute resolution before the courts of the country. In this way, the parties to the contractual relationship protect their rights, but also their interests, in a fair and equal manner. It is almost impossible for one party to know all the rights of the states of the other contracting parties with which it concludes international agreements, and that ignorance of the rights could be to its detriment, and we must not ignore the fact that proceedings before regular courts can take a long time. in foreign trade, agree on arbitral settlement of disputes. Prior to the arbitration of a dispute, the parties almost always state in the contract itself a clause on peaceful settlement of disputes, in a friendly manner, but

${ }^{41}$ Article 49. 
almost always give priority to arbitration, in relation to dispute resolution before the courts of the country. In this way, the parties to the contractual relationship protect their rights, but also their interests, in a fair and equal manner. It is almost impossible for one party to know all the rights of the states of the other contracting parties with which it concludes international agreements, and that ignorance of the rights could be to its detriment, and we must not ignore the fact that proceedings before regular courts can take a long time. the contracting parties almost always state in the contract itself a clause on the peaceful settlement of disputes, in a friendly manner, but they almost always give priority to arbitral settlement of disputes, in relation to the settlement of disputes before the courts of the country. In this way, the parties to the contractual relationship protect their rights, but also their interests, in a fair and equal manner. It is almost impossible for one party to know all the rights of the states of the other contracting parties with which it concludes international agreements, and that ignorance of the rights could be to its detriment, and we must not ignore the fact that proceedings before regular courts can take a long time. the contracting parties almost always state in the contract itself a clause on the peaceful settlement of disputes, in a friendly manner, but they almost always give priority to arbitral settlement of disputes, in relation to the settlement of disputes before the courts of the country. In this way, the parties to the contractual relationship protect their rights, but also their interests, in a fair and equal manner. It is almost impossible for one party to know all the rights of the states of the other contracting parties with which it concludes international agreements, and that ignorance of the rights could be to its detriment, and we must not ignore the fact that proceedings before regular courts can take a long time. but they also protect each other's interests, in a fair and equal way. It is almost impossible for one party to know all the rights of the states of the other contracting parties with which it concludes international agreements, and that ignorance of the rights could be to its detriment, and we must not ignore the fact that proceedings before regular courts can take a long time. but they also protect each other's interests, in a fair and equal way. It is almost impossible for one party to know all the rights of the states of the other contracting parties with which it concludes international agreements, and that ignorance of the rights could be to its detriment, and we must not ignore the fact that proceedings before regular courts can take a long time. 


\section{Conclusion}

Foreign trade business is increasingly widespread today due to technical and technological development and the need of countries to socio-economically develop and expand their market beyond the borders of their country, to the international market. The journey was not easy. Countries were forced to accept certain solutions that their legal system may not have provided for, and even after the recognition or ratification of international treaties, a series of adjustments to domestic law, the law of international communities, and international law followed.

However, in real life and in law, for the sake of success, certain sacrifices and acceptance of certain seemingly impossible solutions are needed, which over time have become established and the feeling of any form of "sacrifice" has been overcome. In particular, through the citation of a couple of solutions regarding foreign trade turnover in the sales contract, it is concluded that the Vienna Convention does not deviate much from the solution prescribed by the Law on Obligations of the Republic of Serbia. Moreover, the individual solutions are almost identical, and the Convention provides the possibility for the contracting parties to regulate their contractual relationship in a different way. Therefore, it does not bind the contractual relationship to the strict application of the Convention, but the contracting parties have full autonomy to regulate certain issues differently than prescribed. The autonomy of the will of the contracting parties in foreign trade operations is reflected in the right to choose the applicable law as well as the jurisdiction of the court.

By dealing with the right to compensation for non-performance of a contractual obligation both in the law of the Republic of Serbia and in the Vienna Convention, it can be noticed that the provisions are rather sparse. Namely, both the law and the Convention, regulate the institute of damages, I will define it as the damage suffered due to non-performance or delay of the contractual obligation of the other party plus lost profits if he suffered it without prescribing other ways of resolving the breach of contractual obligation due to non-performance or delay. Both the law and the Convention, as a consequence of non-performance of a contractual obligation, prescribe only damages in the form of monetary restitution. Cash compensation is a form of compensation and satisfaction, but it can never fully compensate for the loss suffered by non-performance of the contractual obligation of the other party to the contract, and this is especially evident in foreign trade operations 
where a sales contract may be the first in a series of contracts. or could be contracted. ${ }^{42}$

Therefore, the authors support the opinion of PhD Ivica Jankovec that as the law, the Convention should also provide for the provision of enforcement of a contractual obligation, and only if it is impossible for the injured party to be compensated with monetary compensation. In that way, the parties will not approach the contract recklessly, but will quite realistically consider all the circumstances and the possibility of fulfilling the contractual obligation in general, and then commit to the contract.

\section{Praštalo Tanja}

Doktorand, Pravni fakultet za privredu i pravosuđe u Novom Sadu, Univerzitet Privredna akademija u Novom Sadu

\section{Đurđev Dušanka}

Dr, Redovan profesor, Pravni fakultet za privredu i pravosuđe u Novom Sadu, Univerzitet Privredna akademija u Novom Sadu

\section{NAKNADA ŠTETE ZBOG NEIZVRŠENJA UGOVORNE OBAVEZE KOD KUPOPRODAJNOG UGOVORA U SPOLJNOTRGOVINSKOM POSLOVANJU}

REZIME: Jedna od najstarijih ljudskih delatnosti su promet robe, usluga,
novca i drugih imovinskih vrednosti kako unutar jedne zemlje, tako i izvan
njenih granica. Spoljnotrgovinsko poslovanje je od izuzetnog značaja za
društveno-ekonomske odnose među državama. Svaka država samostalno
reguliše promet robe i usluga. Ipak, nijedna privreda države nije sama
po sebi dovoljna, tako da je sasvim opravdana potreba da se uključuju
na međunarodna tržišta. Međusobnom trgovinskom saradnjom, države

\footnotetext{
${ }^{42}$ Purchase of certain goods (eg plowing machines) from one country, which are to be subsequently imported, exported to another country in order to be sold to a third country. In the meantime, a contract on storage, forwarding, etc. should be concluded.
} 
prenose dejstva zaključenih ugovora izvan njenih granica, te je potreba za unifakacijom pojedinih normi preko neophodna, kao i regulisanje pitanja povrede ugovorne obaveze i naknade štete kao posledice iste. Pojedine države strahuju da ratifikacijom međunarodnih pravila prihvataju rešenja koja bi bila u suprotnom sa njihovim nacionalnim zakonodavstvom. Navedeno je samo jedan od niza razloga otpora država, a ujedno i poteškoća u ostvarivanju jedinstvenog prihvatljivog rešenja. $U$ ovom radu je analiziran pojam, značaj spoljnotrgovinskog poslovanaja za države, zatim prava i obaveze ugovornih strana i naknada štete zbog povrede ugovorne obaveze neizvršenjem kod kupoprodajnog ugovora.

Ključne reči: spoljnotrgovinsko poslovanje, prava i obaveze iz kupoprodajnog ugovora, neizvršenje ugovorne obaveze, Bečka konvencija, naknada štete.

\section{References}

1. Antonijević, Z. (1967). Pravo spoljne trgovine [Foreign trade law]. Beograd, Prosveta

2. Antić, O. (2009). Obligaciono pravo [Obligation law]. Beograd, Službeni glasnik

3. Bikić, A. (2007). Obligaciono pravo - opći deo [Obligation law - general part]. Sarajevo, Pravni fakultet Univerziteta u Sarajevu

4. Ćirić, A. (2013). Pravo spoljne trgovine [Foreign trade law]. Niš, Centar za publikacije Pravnog fakulteta u Nišu

5. Đorđević, Ž., Stanković, S. (1987). Obligaciono pravo - opšti deo [Obligation law - general part]. Beograd, IRO Naučna knjiga

6. Goldštajn, A. (1980). Konvencija Ujedinjenih naroda o ugovorima o međunarodnoj prodaji robe $u$ strukturi prava međunarodne trgovine [United Nations Convention on Contracts for the International Sale of Goods in the Structure of International Trade Law]. Zagreb, Informator

7. Jankovec, I. (1987). Naknada za štetu zbog povrede ugovora [Compensation for damage due to breach of contract]. Beograd, Zavod za organizaciju poslovanja i obrazovanje kadrova

8. Perović, J. (2004). Bitna povreda ugovora - međunarodna prodaja robe [Significant breach of contract - International sale of good]. Beograd, JP Službeni list SCG 
9. Radovanov, A. (2009). Obligaciono pravo - opšti deo [Obligation law - general part] Novi Sad, Pravni fakultet za privredu i pravosuđe, Univerzitet Privredna akademija u Novom Sadu

10. Tešić, M. (1977). Spoljnotrgovinsko poslovanje [Foreign trade business]. Beograd, Savremena administracija

11. Vilus, J. (1985). Konvencija Ujedinjenih nacija o ugovorima i međunarodnoj prodaju robe - Bečka konvencija [United Nations Convention on Contracts and the International Sale of Goods - Vienna Convention]. Beograd, Jugoslavija publik

12. Zakon o spoljnotrgovinskom poslovanju [Law on Foreign Trade Operations], Službeni glasnik RS, br. 36/09, 36/11 - dr. zakon, 88/11 i $89 / 15$ - dr. zakon

13. Zakon o ratifikaciji konvencije Ujedinjenih nacija o ugovorima o međunarodnoj prodaji robe [Law on Ratification of the United Nations Convention on Contracts for the International Sale of Goods], Službeni list SFRJ Međunarodni ugovori, br. 101/84

14. Zakon o obligacionim odnosima [Law on Obligations], Službeni list SFRJ, br. 29/78, 39/85, 45/89 - odluka USJ i 57/89, Sl. list SRJ, br. 31/93 i Službeni list $S C G$, br. 1/03 - Ustavna povelja

15. Zakon o parničnom postupku [Law on Civil Procedure], Službeni glasnik $R S$, br. 72/11, 49/13 - odluka US, 74/13 - odluka US, 55/14 i 87/18

16. Judgment of the Commercial Court of Appeal, Pž. 10784/2010 of 6 July 2011 years 